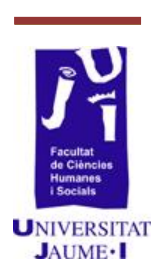

\title{
Welsh Language Maintenance in Education Media
}

Miguel Angel Pitarch Santos woner84@hotmail.com 


\begin{abstract}
The aim of this paper is to show the way Welsh language is established nowadays in Wales in terms of education and media taking into account several aspects such as newspapers, radio or television. In order to clarify how the maintenance is made I have studied the evolution of the already mentioned aspects. Consequently this led me to the fact that although the number of Welsh speakers is not very high the language has a strong environment which supports it and makes Welsh grow day by day.
\end{abstract}

Keywords: Wales, Celtic languages, Welsh language, maintenance, minority language, Cymro, BBC radio Cymru, S4C.

\title{
II. Introduction
}

Minority languages have always been a concern for many linguists and researchers. According to the European Charter for Regional or Minority Languages, minority languages mean languages that are "traditionally used within a given territory of a State by nationals of that state who from a group numerically smaller than the rest of the State's population; and different from the official language(s) of that state". Out of the 6.000-7.000 languages spoken worldwide, a high number of them are considered minority languages in every country in which they are spoken, many of them considered also to be official. Occasionally some of them are marginalized within their nation for a number of reasons. Firstly, the small number of speakers of a minority language creates instability in the maintenance of such language. Secondly the lack of support by the government in terms of policy and education is also considered a factor that harms the maintenance of a minority language. In Europe there are many minority languages spoken by millions. For instance, Catalan language is the most important minority language spoken in Spain and one of the most spoken in the EU (European Union). There are even more Catalan speakers than Irish or Maltese speakers. The maintenance of minority languages is one of the aspects that many experts try to study in order to find the most relevant facts that make it happen. According to Edwards (2010) the maintenance of a minority language depends on the linguistic power that the neighbour language(s) has. This article focuses on one minority language in particular, the Welsh language. I chose to make a study on this language because, to my view, a high amount of people do not even know that in Wales there is an old language that has been spoken for centuries and that is achieving a high status step by step. I attempt to dissect the maintenance of Welsh in terms of education and media in order to show the importance of this language and also to claim, within my possibilities, its maintenance and its status. 
According to Graham Root (source Linguata webpage) there are six Celtic communities language today: Irish, Breton, Scottish Gaelic, Cornish, Manx and Welsh. This group of languages belong to the Indo-European language family and it comes from older forms known as proto-Celtic which were spoken by tribes across Europe in the Iron Age. This is also classified into two sub-groups: Brythonic and Goidelic; Welsh, Breton and Cornish belong to the Brythonic while Irish, Scottish Gaelic and Manx belong to the Goidelic.

Breton is currently being spoken in parts of Brittany, however, most of the speakers are also able to speak French. As many of the Celtic languages, the percentage of Breton speakers had fallen down over the past decades from around 1.000 .000 speakers in 1950 to only 200.000 in the last decade. Regarding Cornish, this language was spoken widely in the region of Cornwall for centuries before the arrival of the predominant English language, nowadays there has been a decreasing of the number of speaker of Cornish although a revival of the language has been carried out for the past years. As for Irish, this language is the most speaking Celtic language nowadays with nearly 2.000 .000 millions of speakers in the Republic of Ireland and considered an official language by the European Union. Scottish Gaelic is not as strong as Irish, the language is native in Scotland and there has been a decline for the past decades that has left the language with a tiny number of speakers, although several linguistics are carrying out a revival of the language. In the case of Manx, this Celtic language is being spoken in the isle of Man but unfortunately there are no more native speakers since the last one passed away in 1974, despite this another revival effort is being carried out.

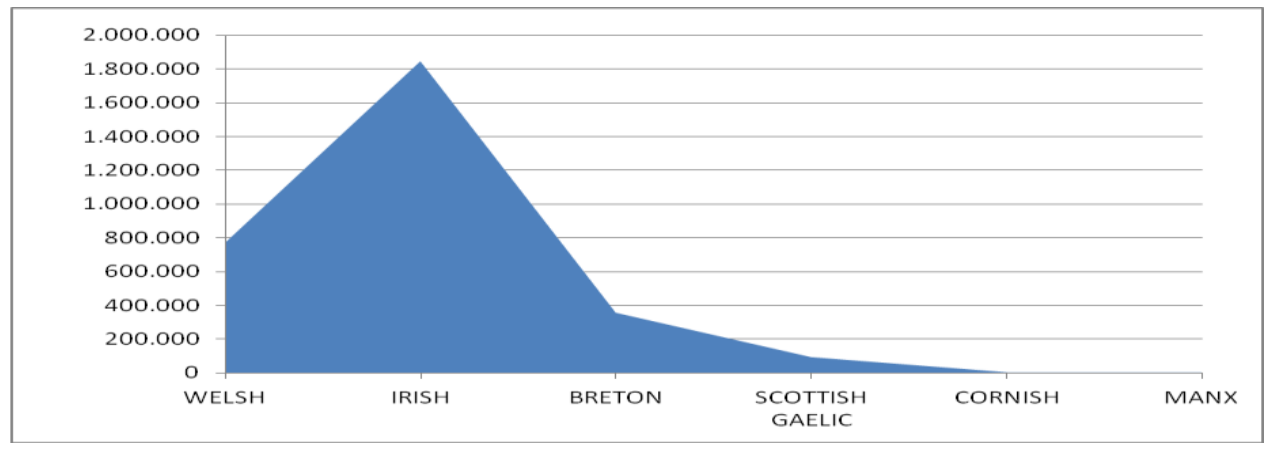

Figure 1. Percentage of speakers of the 6 Celtic languages currently existing (data taken from Celtic FAQ's webpage)

As the figure 2 shows, Irish is the one with the higher amount of speakers followed by Welsh, Breton and Scottish Gaelic do not have many speakers currently while Cornish and Manx are practically disappearing. All these languages have in common that there are several revivals at different 
stages being carried out in order to increase the number of speakers of each one.

As for the one concerning this paper, Welsh is the only one $\overline{-}_{-}$of the currently existing Celtic languages, that has been the longest in the British Isles. The earliest known forms of Welsh come from the $6^{\text {th }}$ century although there are not many examples that remain nowadays due to his antiquity. Just a few texts in the form of poetry have survived from the Old Welsh language. However, it is easier to find more examples in form of poetry and stories from the Middle Welsh. In addition, it was in the $16^{\text {th }}$ century when Welsh had some of the most important developments such as the appearance of the first printed book or the publication of a grammar book. Although there was a huge increasing in the usage of the language in the $18^{\text {th }}$ and $19^{\text {th }}$ centuries, Welsh language started to have, little by little, a decreasing number of speakers of the language due to the expansion of the industry that brought to the country lots of English workers. Moreover, the government wanted to conduct its official business in English when Wales was colonized by England. However, in the last decade the decreasing stopped because of the pressure generated by some organizations who wanted to preserve the language at any price. In addition, the census to verify the number of speakers takes place every decade.

\section{Percentage of Welsh speakers}

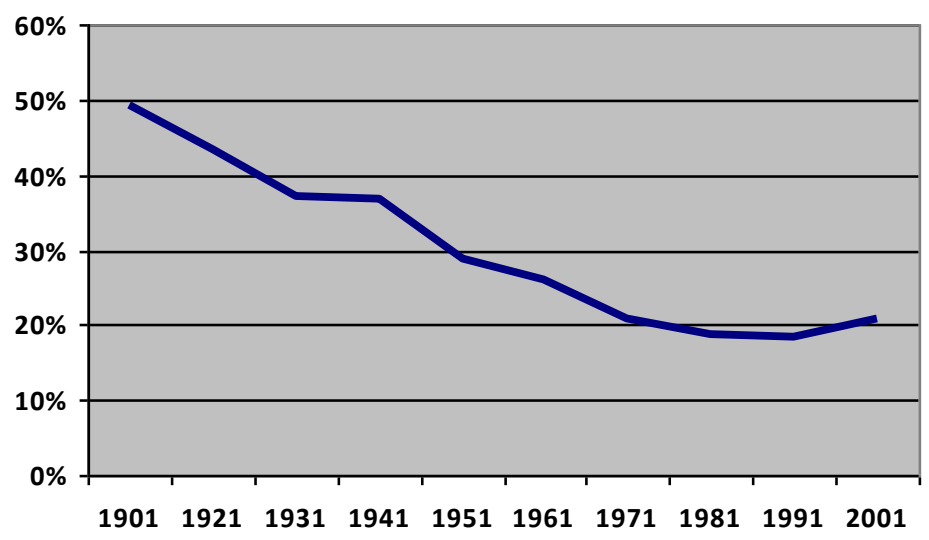

Figure 2. Percentage of Welsh speakers between the years 1901 and 2001 (data taken from clickon wales.org/Wales factfiles webpage)

As the figure 2 shows, there has been a regular decreasing of Welsh speakers in the last century but there finally was an increasing in the last census which confirms that the effort made by the organizations had a positive effect. 

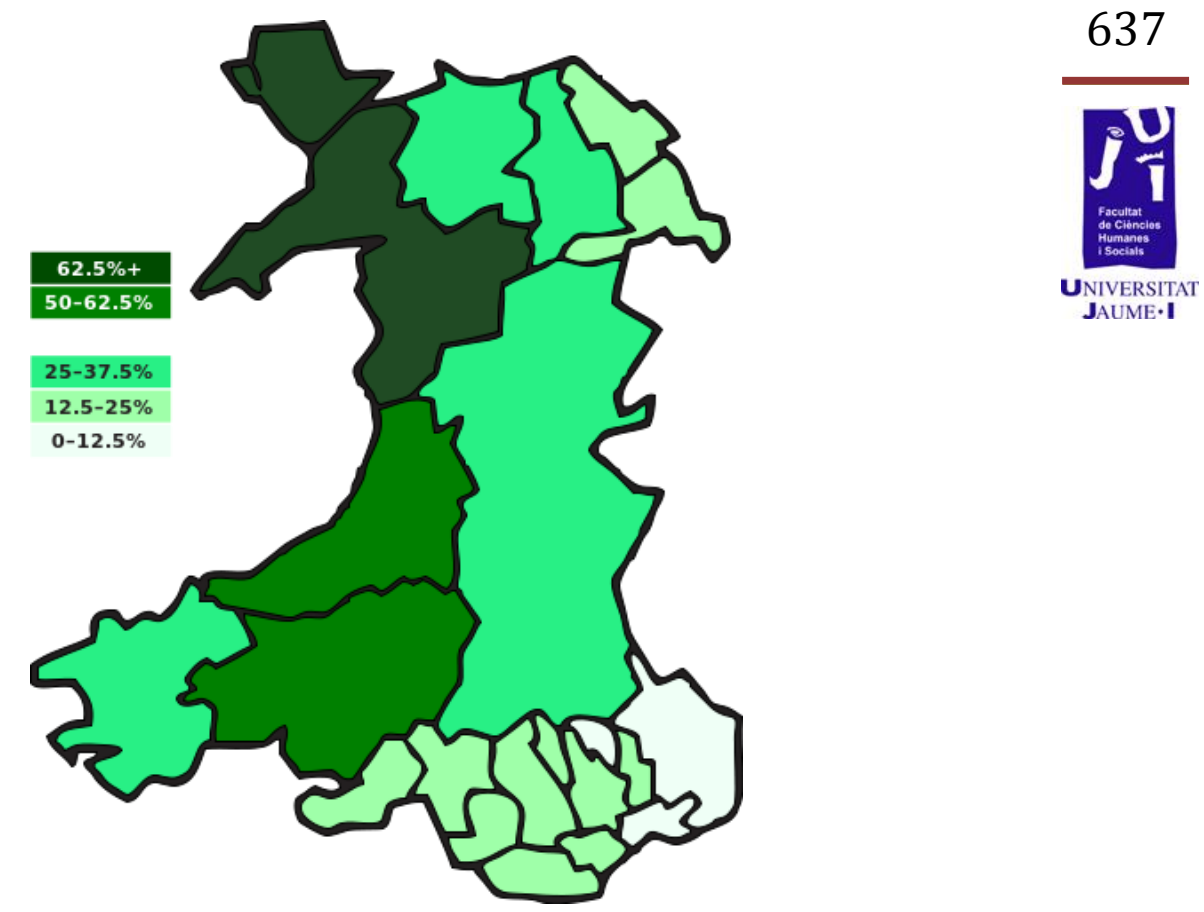

Figure 3. Map of Wales with the percentages of Welsh in different regions (data taken from Welsh Language Commissioner webpage)

As the figure 3 shows, most of the Welsh speakers are placed in the north-east of the country while in the boundaries with England the number of speakers decreases considerably. However, the purpose of this paper is not to analyze the demographic reasons of the language but to analyze the preservation of Welsh. The ways in which this preservation is made nowadays along with its evolution are further developed in this article in terms of education and media.

\section{Welsh language in terms of education}

The Welsh language was vanished from education in 1870 by the Education Act of that year (Cameron 2001).Otherwise, in the 20th century Welsh was restored as a language in terms of education. On the one hand, the first primary school was established in 1939 in a region with a high amount of Welsh speakers, although it was not supported by public funding until the opening of a school in Llanelli in 1947 (source BBC Homepage Wales Home Education webpage). On the other hand, the first secondary school was opened in 1956 and by 1960 pupils from a nonWales speaking region were sent to schools were Welsh was being taught because it was assumed that those schools had better results in examinations by the students who attended there (source: BBC Homepage Wales Home Education webpage). 
Therefore, there were 28 primary schools in English speaking areas in

1960 in Wales and there was an important increase in 1980 where the number of schools grew up to 67 (Williams 1992). Already in 1990, Welsh became a compulsory subject for all students at the age of fourteen (source: clickonwales.org webpage) and, depending on the circumstances, in $\mathbf{2 0 0 0}$ we could find primary schools that taught the Welsh as a main language or as a secondary language. That fact, leads us to a number of almost 470 schools that are Welsh-medium or bilingual out of 1,600 schools that currently exist in Wales. Concerning the secondary level, there has been also an important increase of schools in terms of teaching Welsh, in 20 years the number went to 42 to 55 (source: clickonwales.org webpage). In the following years is expected to be more schools that take welsh as a second language to take in consideration in the learning process.

\section{Welsh language in terms of media}

Wales has a few newspapers publishing in Welsh language, but it took a long time to have the variety of Welsh newspapers that are being printed nowadays. According to The National Library of Wales (Source LLGC webpage), the very first magazine that got published in Welsh language took place in 1735 as an attempt to maintain the interest of people in Welsh. Unfortunately, Tlysau yr hen oesoedd only lasted one issue. It was not until 1770 when another Welsh journal appeared, along with another three, during the eighteenth century but none of those lasted long. In addition, the first weekly newspaper that got published was named "Seren Gomer" in 1814 (Source LLGC webpage) but ended his publishing after 85 issues due to the tax of the paper made for the newspaper which was too expensive.

During the $20^{\text {th }}$ century it got published probably the most important weekly newspaper in Welsh language, Y Cymro, it lasts until today and it is the only national Welsh newspaper existing (Source British Newspapers Online webpage). Although it was not the first newspaper that used the name Cymro, it was first published in 1932, being the oldest publication still available. Moreover, since 2010 it became available on the internet as a digital newspaper. Although Cymro is the most significant newspaper written in Welsh, there are others available daily such as YC Herald Cymraeg which comes as a supplement in the Welsh edition of the Daily Post or Western Mail which usually includes Welsh columns, but these ones are only printed in specific areas of the country. Furthermore, there are others weekly and monthly newspapers with Welsh content available in specific areas which cover more local issues. In addition, there are also magazines published in Welsh language such as Gowlg which has its own page on the internet called Gowlg360 (source: Gowl360 webpage). 
Another important aspect to take into account in terms of Welsh-media is radio and television. According to Jones (2006), the first radio broadcasting programmes in Welsh appeared in 1923 in BBC but their contents were quite short. Although in 1930 the radio programmes in Welsh language increased and during the 1950s and 1960s were further developed, it was not until 1978 when a radio achieved to broadcasts its content exclusively in Welsh language. The radio was named BBC Radio Cymru and it broadcasts more than 20 hours a day of Welsh language programmes and still continues on doing it nowadays (Jones 2006). It is also the only one today to broadcast fully in Welsh.

Another important radio programme is Swansea Sound which launched in 1974 and offers its contents bilingually (Welsh-English). Besides these ones, there are other significant Welsh radios to be considered. For instance, Coast FM, Radio Ceredigion or Champion FM which only broadcast their contents in Welsh certain hours per week.

Television broadcasting in Welsh came on the scene as well step by step. In 1952 BBC television launched in Wales but the contents in Welsh language were very slight, only half an hour per week (Jones 2006). This situation lasted for many years although there were attempts, made by television companies, to broadcast bilingually. For example, Teledu Cymru which appeared in 1962 and ended in 1964 due to financial problems. In the 1960 s and the 1970 s television programmes in Welsh were being broadcast by $B B C$ and the hours of Welsh contents were already between 6-7 hours per week. However, those programs were broadcast at not such regular times so the audience rate was not very high.

Finally, in 1982 was launched S4C television channel, which was a partner of the successful Channel 4 in the UK. The channel is bilingual and broadcasts 32 hours of Welsh content per week, usually from 6 p.m. to 10 p.m., and it is the most important Welsh channel existing nowadays. Moreover, in 2010 S4C became an independent channel due to the arriving of the digital television and its contents started to broadcast entirely in Welsh language. Also S4C-2 was launched in 1999 as a bilingual channel but it was closed in January 2011 when S4C was already broadcasting fully in Welsh.

One last factor that makes Welsh maintenance possible today, is the presence of the language on the internet. According to Wikipedia (source Wikipedia webpage) Welsh language is placed nowadays at number 68 out of 285 languages publishing articles in this website. Wikipedia is a very valuable source in order to get to know how a language is present on the net as it is a tool used by millions. Above this it is interesting to mention that the most important online page in Welsh is $B B C$ Cymru'r $B y d$, launched in 2000, offering a wide range of different issues about 
sports, news or live-shows. Moreover, the television channel mention before, S4C, has its own webpage in which several Welsh contents are offered online.

VI. Conclusion

The foregoing evidence I have presented leaves little doubt that Welsh is being taking into account in a more important level as time goes by. Education is now more concerned of the language's value and the number of schools that take Welsh as a second language is growing slowly but efficiently. In terms of media, firstly Welsh newspapers are more easily found today than 30 years ago. Secondly, there are many radios broadcasting in Welsh today although only one does it fully in Welsh. Thirdly, it was in $\mathbf{2 0 1 0}$ when the first television on fully broadcast in Welsh was established. Finally, it also seems that the language has a strong presence on the internet. Although the process to achieve the current situation has been taken step by step, the results are completely satisfactory and the language maintenance of Welsh is well supported.

\section{References (MLA citation)}

DYFRIG, RHODRI ap; Jones, Elin and Jones, George. "The Welsh Language in the Media" Mercator Media Monographs. 2006. Web. 1 Dec. 2011. http://www.aber.ac.uk/mercator.

"Education in Welsh". BBC Homepage Wales Home Education. n.d. Web. 30 Nov. 2011. http://www.bbc.co.uk/wales/.

"European Charter for Regional or Minority Languages". Council of Europe. $1992 . \quad$ Web. $25 \quad$ Nov. 2011. http://conventions.coe.int/Treaty/en/Treaties/html/148.htm

EDWARDS, JOHN. "Group identity minority language". Amsterdam; Philadelphia: John Benjamins Pub. co. 2010.

"Golwg360". Golwg360. n.d. Web 10 Dec. 2011. http://www.golwg360.com/newyddion .

Jones, Hywel M. "A Statistical Overview of the Welsh Language" Welsh Language Commissioner. Web. 22 Dec. 2012. http://www.welshlanguagecommissioner.org/English/ Publications $\% 20$ List

/A\%20statistical\%20overview\%20of\%20the\%20Welsh\%20language.pdf 
M. Cameron Arnold. "Wales". Find articles. 2011. Web. 4 Dec. 2011. http://findarticles.com/p/articles/mi_gx5228/is_2001/ai_n19144282/?ta $\mathrm{g}=$ content;col1

"List of Wikipedias" Wikipedia. Web. 22 Dec. 2012. http://meta.wikimedia.org/wiki/List_of_Wikipedias

Root, Graham. "A brief history of the Welsh language". Linguata.n.d. Web. 30 Nov. 2011. http://www.linguata.com/welsh/history-of-thewelsh-language.html

"The first Welsh Weekly". The National library of Wales. n.d. Web. 28 nov. 2011. http://www.llgc.org.uk/index.php?id=528 .

"Welsh language factfile". Clickonwales.org. n.d. Web. 1 Dic.2011. http://www.clickonwales.org/wpcontent/uploads/5_Factfile_Language.pdf .

"What are Celtic Languages" Celtic FAQs. Web. 22 Dec. 2012. http://www.digitalmedievalist.com/faqs/index.html

"Y Cymro". British Newspapers Online. n.d. Web. 4 Dec. 2011. http://www.britishpapers.co.uk/wales/y-cymro/ .

\section{Acknowledgments}

Raúl Pérez Ramos, Jose Valero Mecho and María Noelia Ruíz Madrid. 
